\title{
Heavy metal profiles of agricultural soils in Sakarya, Turkey
}

\author{
Mehmet Isleyen $^{1+}$, Aysegul Akpinar ${ }^{2}$, Beytullah Eren ${ }^{3}$, Gulsun Ok ${ }^{3}$ \\ ${ }^{1}$ Department of Environmental Engineering, Bursa Technical University, Bursa 16130, Turkey \\ ${ }^{2}$ Biotechnology Application and Research Center, Bilecik Seyh Edebali University, Gulumbe-Bilecik 11230, Turkey \\ ${ }^{3}$ Department of Environmental Engineering, Sakarya University, Sakarya 54187, Turkey
}

\begin{abstract}
Sakarya is famous for cucurbit productions in Turkey and cucurbits can grow as big as $560 \mathrm{~kg}$ of weight per fruit in its agricultural areas. There is no or limited information about contaminant levels and profiles of the agricultural fields in Sakarya. The purpose of this study is to investigate the levels of polycyclic aromatic hydrocarbons (PAHs) (naphthalene, phenanthrene, pyrene, and fluoranthene) and heavy metal (As, $\mathrm{Cd}$, $\mathrm{Cu}$, $\mathrm{Cr}, \mathrm{Ni}, \mathrm{Pb}, \mathrm{Zn}$ ) concentrations of the selected fields. Total 33 soil samples were collected from 12 counties of Sakarya where both cucurbits have been produced and organochlorine pesticides have been applied to the fields for more than $30 \mathrm{y}$ during the historical plantation periods. Heavy metal and PAH contents in the soil samples were measured by an Inductively Coupled Plasma Emission Spectroscopy and a Gas Chromatography-Mass Spectrometry. The highest phenanthrene, pyrene, and fluoranthene concentrations were measured as $63.50 \mathrm{ng} / \mathrm{g}, 134.34$ $\mathrm{ng} / \mathrm{g}$, $140.0 \mathrm{ng} / \mathrm{g}$, respectively in the soil samples from Geyve County. $\mathrm{Cu}, \mathrm{Ni}$, and Cr concentrations were measured as $108.2 \mathrm{mg} / \mathrm{kg}$, $219.9 \mathrm{mg} / \mathrm{kg}$, and $173.1 \mathrm{mg} / \mathrm{kg}$, respectively in Geyve's samples which were also the highest and 2-7 times more than the limit values given in the Turkish Soil Pollution Control Regulation. Precautions need to be taken for Sakarya's agricultural fields which are an important milestone of Turkey's cucurbit and fruit productions since the contaminants can be accumulated in the fruits and edible parts of the plants.
\end{abstract}

Keywords: Agricultural, Cucurbits, Heavy metals, PAHs, Sakarya

\section{Introduction}

Agricultural soils contaminated with pesticides, polycyclic aromatic hydrocarbons (PAHs), and heavy metals are of great concern all over the world. PAHs produced by natural processes and human activities such as coal gasification, refinery operations, and incineration may accumulate in the soils $[1,2]$. These pollutants in the air can spread out with the atmospheric movements and travel to the long distance until settling down to the surfaces of soil and water bodies [3]. Therefore, even if there are no agricultural activities in the Arctic, bioaccumulation of PAHs, heavy metals, and pesticides in arctic plants and animals have been commonly found in screening and monitoring studies for many decades [4-13]. Once adsorbed on to soil, they are relatively stable and their degradations in the soil are much more difficult than many other organic compounds, resulting in accumulation in soil structures over the time. PAHs may cause vital problems such as carcinogenic and mutagenic effects on organisms by accumulating along with the food chain from soil to plants and they are well known as recalcitrant and lipophilic contaminants [14]. In this regard, there are many studies that indicate their accumulations and harmful effects from crops and wild plants such as Spartina alterniflora to fish [15-17].

Heavy metals are also stable in the environment and may enter to terrestrial trophic chain from both natural and anthropogenic sources [18-20]. Heavy metals are released from anthropogenic sources such as mining, fossil fuels, urban wastes, fertilizers, industrial plants, and runoff over the contaminated sites into the agricultural soils [21-24]. The toxicity of metals depends primarily on valance state, organic and inorganic forms, solubility, physicals state, purity, and sorption rates. For instance, trivalent arsenic (As(III)) is generally more toxic than pentavalent $\mathrm{As}(\mathrm{V})$ [25], similarly, hexavalent $\mathrm{Cr}(\mathrm{VI})$ is highly toxic and mobile [26] and approximately 100 times more toxic than trivalent $\mathrm{Cr}$ (III) [27]. The effects of metal toxicity can be varied based upon their valance states where they form poisonous soluble compounds and complexes in aqueous phase solution. In general, heavy metals such as cadmium $(\mathrm{Cd})$, lead $(\mathrm{Pb})$, arsenic (As) and chromium (Cr) create toxic effects by complex formations with organic compounds even at low concentrations [28, 29]. Those
This is an Open Access article distributed under the terms of the Creative Commons Attribution Non-Commercial License (http://creativecommons.org/licenses/by-nc/3.0/) which permits unrestricted non-commercial use, distribution, and reproduction in any medium, provided the original work is properly cited.

Copyright (C) 2019 Korean Society of Environmental Engineers
Received August 6, 2018 Accepted October 11, 2018

${ }^{\dagger}$ Corresponding author

Email: mehmet.isleyen@gmail.com

Tel: +90-224-300-3596 Fax: +90-224-300-3419

ORCID: 0000-0001-5011-977X 
metals can enter to the roots through symplastic or apoplastic pathways because there is no need to a specific transport system for their uptake by plants. Thus, heavy metals damage to the mineral nutrition of plants by competing with essential mineral nutrients [30]. These metals not only accumulate in plant tissue or cell compartments after their uptake but also they inhibit metabolic functions and growth, resulting in the death of organisms.

Metals such as iron (Fe), zinc (Zn), copper $(\mathrm{Cu})$, nickel $(\mathrm{Ni})$ known as micronutrients are necessary for plants. Although their presence in trace $(10 \mathrm{mg} / \mathrm{kg}$, or $\mathrm{mg} / \mathrm{L})$ or in ultra-trace $(1 \mu \mathrm{g} / \mathrm{kg}$, or $\mu \mathrm{g} / \mathrm{L}$ ) amounts in the environmental matrices is sufficient for the plants [31], they are toxic for living organisms at high concentrations [32]. Metal deficiency and toxicity play a crucial role in plants since they are involved in many physiological and metabolic processes such as respiration, photosynthesis, and biosynthesis of hormones. Such negative effects of heavy metals on plants may over time lead to the complete disappearance of natural vegetation in the contaminated areas over the time.

The anthropogenic contribution of the metals in the biosphere is increasing day by day due to industrial and urban activities. This situation raises gradually the pressure on the environment. Phytoremediation, soil amendments such as nanoparticles and sorbents, soil washing with biosurfactant may use to remediate the fields contaminated with inorganic or organic pollutants [33-41]. However, this is out of the scope of this research. The problems of contaminated sites have also begun to emerge in Turkey's heavily industrialized regions. Sakarya Province is one of the most contaminated sites in Turkey. Presumably, this situation has been created by both industrial activities in heavily polluted regions and agricultural uses of the lands for many decades. It is reported that Cucurbita pepo spp. pepo has the ability to extract persistent organic pollutants (POPs) such as $p, p$ '-DDE and chlordane from the soil and the amount of extracted POPs in plant compartments varied based upon plant type and sub-species [42-44]. The biggest Cucurbita moschata in Turkey, growing as big as $560 \mathrm{~kg}$ per fruit, are obtained from agricultural fields of Sakarya every year. Approximately 10\% of the fruits and $5 \%$ of the cucurbit productions of Turkey are obtained from agricultural fields in Sakarya [45]. Presumably, pesticides and soil amendments have been excessively used to obtain enhanced crop productions in the fields of Sakarya for many decades and organic and inorganic pollutants might be accumulated by the plants, crops, and fruits grown in the fields. Unfortunately, there is no or limited information about contaminant levels in agricultural areas of Sakarya [46]. This study investigates the levels of PAHs (naphthalene, phenanthrene, pyrene, and fluoranthene) and heavy metals (As, Cd, Cu, $\mathrm{Cr}, \mathrm{Ni}, \mathrm{Pb}, \mathrm{Zn}$ ) in agricultural soils at where both cucurbits have been produced and organochlorine pesticides have been applied to the fields in Sakarya for more than $30 \mathrm{y}$ during the historical plantation periods. This research may lead to a further investigation of heavy metal and PAH accumulations in the food chain.

\section{Materials and Methods}

\subsection{Sampling Site}

Agricultural fields in Sakarya were carefully selected among the fields based upon a "yes" answer from a detailed survey study asking the following 2 targeted question: Have the fields been continuously used for cucurbits productions at least for $30 \mathrm{y}$ ? And have organochlorine pesticides been applied to the fields during the historical plantation periods? Sakarya has 12 counties which are Ferizli, Kocaali, Sogutlu, Pamukova, Hendek, Adapazari, Kaynarca, Karasu, Akyazi, Karapurcek, Sapanca, and Geyve. Based upon the survey results, the number of agricultural fields to collect soil samples ranged from 1 to 5 for the counties. For instance, while only one agricultural field was sufficient enough to meet Survey's criteria, Geyve County has 5 sampling fields. Selected total agricultural 33 areas are given in Table 1 and Fig. 1.

Since POPs such as $p, p$ '-DDE and chlordane are accumulated in 0-30 cm depths of soil [47], soil samples were collected from 0-20 cm depth from the surface soil. After plants, roots, and other impurities were removed from $0-5 \mathrm{~cm}$ subsurface, approximately 600 gram of the soil samples were collected in a container by

Table 1. Agricultural Soils Collected from the Counties of Sakarya

\begin{tabular}{lc}
\hline Sample location & Sample ID \\
\hline Ferizli & FER-1 \\
Kocaali & FER-2 \\
& KOC-1 \\
& KOC-2 \\
Sogutlu & KOC-3 \\
& SOG-1 \\
Pamukova & SOG-2 \\
& SOG-2 \\
Hendek & PAM-1 \\
Adapazari & PAM-2 \\
Kaynarca & PAM-3 \\
HEN-1 \\
Karapurcek
\end{tabular}






Fig. 1. Soil samples collected from agricultural fields in Sakarya.

a soil corer at $5 \mathrm{~cm}, 10 \mathrm{~cm}, 15 \mathrm{~cm}$, and $20 \mathrm{~cm}$ depths from 20 different spots of the each selected field in September of 2009. Collected soil samples were well mixed into a wide mouth bowl and sieved through $2 \mathrm{~mm}$ mesh sieve in order to remove rocks and other debris. Sieved soil samples kept into both $250 \mathrm{~mL}$ of plastic bottles for metal and pre-baked $250 \mathrm{~mL}$ of glass bottles for $\mathrm{PAH}$ analyses were transferred in a $20 \mathrm{~L}$ container packed with ice bags to the laboratory.

\subsection{Analysis for Heavy Metals}

All soil samples were extracted using a slightly modified method that had been previously published [48]. Soil samples were dried at room temperature for $7 \mathrm{~d}$. The samples were sieved through a 16-mesh screen to remove impurities. Then two portions of soil samples were used for moisture content estimation and digestion purposes. A $1.0 \mathrm{~g}$ of soil samples was kept in an oven at $105^{\circ} \mathrm{C}$ for $24 \mathrm{~h}$ in order to calculate moisture contents of the samples. For digestion, $0.5 \mathrm{~g}$ of sieved soil samples was digested with 15 $\mathrm{mL}$ of concentrated $\mathrm{HNO}_{3}$ on a hot plate at $90^{\circ} \mathrm{C}$ for $50 \mathrm{~min}$ and the digested extracts were filtered in through the $0.22 \mu \mathrm{m}$ syringe filters. Metal concentrations in the filtered samples were measured by an Inductively Coupled Plasma Emission Spectroscopy (ICP OES). For quantitation of soil samples, calibration standards containing a mixture of $\mathrm{Zn}, \mathrm{Ni}, \mathrm{Cu}, \mathrm{Cr}, \mathrm{Pb}$, and As were prepared in distilled water containing $10 \%$ of $\mathrm{HNO}_{3}$ at, $0,0.1,1,2.5,5$, 10,20 , and $50 \mathrm{mg} / \mathrm{L}$ and injected at the beginning and end of runs. The detection limits of the instrument for $\mathrm{Zn}, \mathrm{Ni}, \mathrm{Cu}, \mathrm{Cr}$, $\mathrm{Pb}$, and As were $20 \mu \mathrm{g} / \mathrm{L}, 16 \mu \mathrm{g} / \mathrm{L}, 10 \mu \mathrm{g} / \mathrm{L}, 5 \mu \mathrm{g} / \mathrm{L}$, and $18 \mu \mathrm{g} / \mathrm{L}$, respectively.

\subsection{Quantitation of PAHs in Soil}

Dried soil samples at room temperature for $7 \mathrm{~d}$ were sieved through a 16-mesh screen and divided into two fractions. For the first fraction, $1.0 \mathrm{~g}$ of soil samples was kept in an oven at $105^{\circ} \mathrm{C}$ for $24 \mathrm{~h}$ in order to calculate moisture content. A-10 g of soil sample used for the second fraction was spiked with $200 \mu \mathrm{g}$ of $\mathrm{d}_{10}$-fluoranthene, $\mathrm{d}_{10}$-phenanthrene, and $\mathrm{d}_{10}$-pyrene as internal standards (IS) prior to extraction. Dichloromethane: Acetone ratio (1:1) was added into soil samples were extracted in a Soxhlet apparatus for $16 \mathrm{~h}$. Extracted samples were cleaned up and exchanged with proper solvent based upon previously published method [49]. A-1 mL of samples were transferred into $2 \mathrm{~mL}$ GC vials and PAHs concentrations in the extracts in $2 \mathrm{~mL}$ GC vials were quantified on an Agilent GC/MS system with a modified GC oven program published previously [49]. Mass spectrometer scan ranges were set to 6 min filament delay; 6-13 $\mathrm{min}, \mathrm{m} / \mathrm{z}$ 120-140; 13-31 $\mathrm{min}, \mathrm{m} / \mathrm{z}$ 145-170; 31-46 min, $\mathrm{m} / \mathrm{z}$ 170-195; $46-53 \mathrm{~min}, \mathrm{~m} / \mathrm{z}$ 265-345; 53-85.5 min, m/z 195-425; 85.5-92 $\mathrm{min}, \mathrm{m} / \mathrm{z}$ 220-340; 92-116 min, m/z 220-250. For quantitation of soil samples, calibration standards containing a mixture of PAHs were prepared in hexane at 10, 25, 50, 100, 250, 500, and 1,000 $\mu \mathrm{g} / \mathrm{L}$ and injected at the beginning of runs. The detection limits of the instruments for naphthalene, phenanthrene, pyrene, and fluoranthene were $0.5 \mu \mathrm{g} / \mathrm{L}, 1 \mu \mathrm{g} / \mathrm{L}, 2 \mu \mathrm{g} / \mathrm{L}$, and $1.5 \mu \mathrm{g} / \mathrm{L}$, respectively.

For PAHs and metal concentrations of the soil sample, an average value of the runs obtained from 5 separate extractions of the sieved soil sample in the container collected from each sampling location are given as ng and mg of contaminant per $\mathrm{kg}$ of collected original soil sample on a dry weight basis, respectively. For statistical analysis, one-way analysis of variance (ANOVA) was applied to the data. All statistical tests were performed at a significance level of 0.05 using SPSS Statistics and Gomes-Howell or Tukey test was applied to check the homogeneity of variances.

\section{Results and Discussion}

\subsection{PAHs}

$\mathrm{PAH}$ concentrations were given in Fig. 2. Naphthalene, phenanthrene, pyrene, and fluoranthene concentrations ranged (1.64-20.34 ng/g), (4.24-63.5 ng/g), (1.29-134.44 ng/g), (1.34-140 ng/g), respectively. Based upon the results, except naphthalene concentration, the highest PAH levels were obtained from a sample called GEY-1 collected from Geyve County. The busiest highways in the region pass through the Geyve. Similar to our data, the high levels of $p, p^{\prime}$-DDT and $p, p^{\prime}$-DDE concentration were reported in agricultural soils in Geyve [46]. Second high PAH concentrations were measured in KOC-1 sample from Kocaali County at where agricultural areas lie along with coast of the Black Sea. Kocaali County is close to Istanbul which is the most crowded city in Turkey and its population increases 5-6 times in the summer season due to tourism. The most common ways of Pyrogenic PAH sources are released from combustion of petroleum, coal, and exhausts of motor vehicles Telli-Karakoc et al. [50] reported that PAHs appear in most urbanized coastal areas of Turkey.

\subsection{Heavy Metals}

$\mathrm{Ni}$, Cu, and $\mathrm{Zn}$ concentrations, known as micronutrient elements, are shown in Fig. 3. None of the values obtained for Zn concentrations, except KOC-1 sampling field, was statistically different from each other $(p<0.05)$. Zn concentration in KOC-1 sample was $201.1 \mathrm{mg} / \mathrm{kg}$ soil which is more than $150 \mathrm{mg} / \mathrm{kg}$ of the limit 


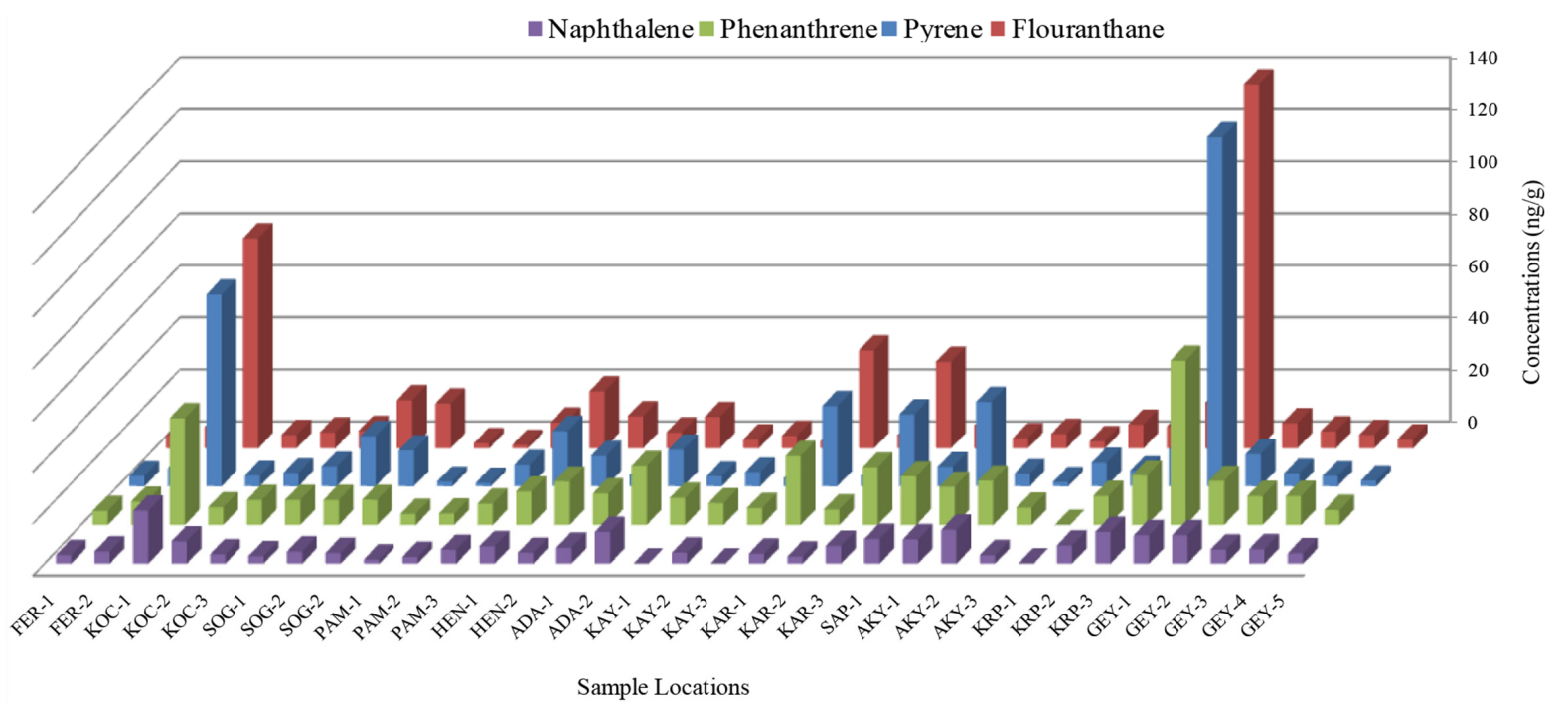

Fig. 2. PAH average concentrations in agricultural soils collected from Sakarya. Average concentration is given as ng PAH per g of collected soil on a dry weight basis.

value in the Turkish Soil Pollution Control Regulation (TSPCR). Zinc is a toxic element for plants and Zn toxicity is usually seen in urban soils and in agricultural soils amended with sewage sludge. $\mathrm{Zn}$ causes Fe deficiency and chlorosis in plant species grown in contaminated fields due to the antagonistic relationship a between $\mathrm{Zn}$ and Fe [51]. At the toxic level, Zn also accumulates in aquatic organisms and results in death. It is likely that $\mathrm{Zn}$ toxicity may affect the ecosystem by entering into the aquatic environment in Kocaali, which is the coastal county of Sakarya.

$\mathrm{Ni}$ concentrations in the soil samples ranged from 3.0 to 219.9 $\mathrm{mg} / \mathrm{kg}$ with an average value of $67.1 \mathrm{mg} / \mathrm{kg}$ which is statistically significant $(p<0.05)$. Ni concentrations in $78 \%$ of soil samples were above the threshold value which is $30 \mathrm{mg} / \mathrm{kg}$ given in the TSPCR. For Ni concentrations, Geyve, Sapanca, Adapazari, and Pamukova Counties (GEY-2, GEY-3, GEY-4, GEY-5, SAP-1, ADA-2, PAM-3) were found to be the most contaminated fields. Similar to our data, Altundag et al. [52] also reported that the Ni concentrations in the samples from Geyve were the high levels. Duman et al. [53] reported the toxic Ni concentrations in surface sediments of the Lake Sapanca. Similarly, the same pathway for Ni was observed in soil samples collected from the roadsides where the major highway passes through Sapanca County [54]. Different nickel compounds such as acetate, nickel carbonate, nickel hydroxide, and nickel sulfate are used as a raw material in textile plants and other industrial processes commonly found in this region, resulting in increases in the environmental samples [55]. Plant growth and development are negatively impacted by Nickel toxicity due to adverse effects on the nitrogen metabolism of a living organism [54].

An excess amount of $\mathrm{Cu}$ may lead to irreversible metabolic problems despite being an essential micronutrient for plant growth. In our study, $\mathrm{Cu}$ concentrations in the GEY-1 and GEY-5 samples showed significant differences and ranged from 105.9 to 108.2 $\mathrm{mg} / \mathrm{kg}$ soil which is 2.16 times more than that of the value given in TSPCR. There was no statistically significant difference between the other samples except GEY-1 and GEY-2 samples ( $p<0.05)$.
Our data showed that soils in Geyve County were the most contaminated with $\mathrm{Cu}$ and as well as other heavy metals. The similar pathway was seen in $p, p$ '-DDE concentrations in agricultural soils in Geyve [46].

A $10-15 \%$ of total fruits productions of Turkey were produced in Geyve, Sakarya [45]. Sakarya River, the $3^{\text {rd }}$ longest river with a length of $824 \mathrm{~km}$ in Turkey, flows northward through Geyve to drain into the Black Sea and most of the agricultural fields in Geyve are watered from the river during the growth season. Organic and inorganic pollutants in the Sakarya River might be accumulated in agricultural soils during the uses of river water. Similar to our results, high $\mathrm{Cu}$ levels and organochlorinated pesticides was reported in previous publications [46, 52].

$\mathrm{Cr}, \mathrm{Pb}$, and As concentrations are given in Fig. 4. Cr concentrations ranged from $4.2 \mathrm{mg} / \mathrm{kg}$ to $173.1 \mathrm{mg} / \mathrm{kg}$ with an average value of $46.8 \mathrm{mg} / \mathrm{kg}$. Cr levels in GEY-2, GEY-3, and GEY-4 samples were $173.1 \mathrm{mg} / \mathrm{kg}, 149.5 \mathrm{mg} / \mathrm{kg}$, and $129.4 \mathrm{mg} / \mathrm{kg}$, respectively, and all of which is more than the value of TSPCR which is $100 \mathrm{mg} / \mathrm{kg}$. Samples from Geyve County (GEY-2, GEY-3, GEY-4) were most polluted by $\mathrm{Cr}$, pyrene, and fluoranthene as well as other metals. Presumably, anthropogenic activities such as leather tanning process, electroplating, and application of pesticides having inorganic elements could be the main sources of $\mathrm{Cr}$ in the soils of Geyve County [26].

Average As and $\mathrm{Pb}$ concentrations are shown in Fig. 4 ranged (0.9-18.1) $\mathrm{mg} / \mathrm{kg}$ and $(2.1-27.6) \mathrm{mg} / \mathrm{kg}$. Cd concentration not presented in the Figures was measured up to $0.5 \mathrm{mg} / \mathrm{kg}$. All concentration levels measured for $\mathrm{As}, \mathrm{Pb}$, and $\mathrm{Cd}$ are less than the set values of TSCPR $(20 \mathrm{mg} / \mathrm{kg}$ for As, $50 \mathrm{mg} / \mathrm{kg}$ for $\mathrm{Pb}, 1 \mathrm{mg} / \mathrm{kg}$ for Cd). Contaminants may enter environmental samples due to the veins of quartz-carbonate mining activities containing pyrite, arsenic-bearing and sulfosalt minerals, resulting in an increased amount of pollutants in soil samples or plant growing in the contaminated fields. Car factories, marble, and sand mining activities are widespread in Adapazari County in Sakarya. It is possible that 
the
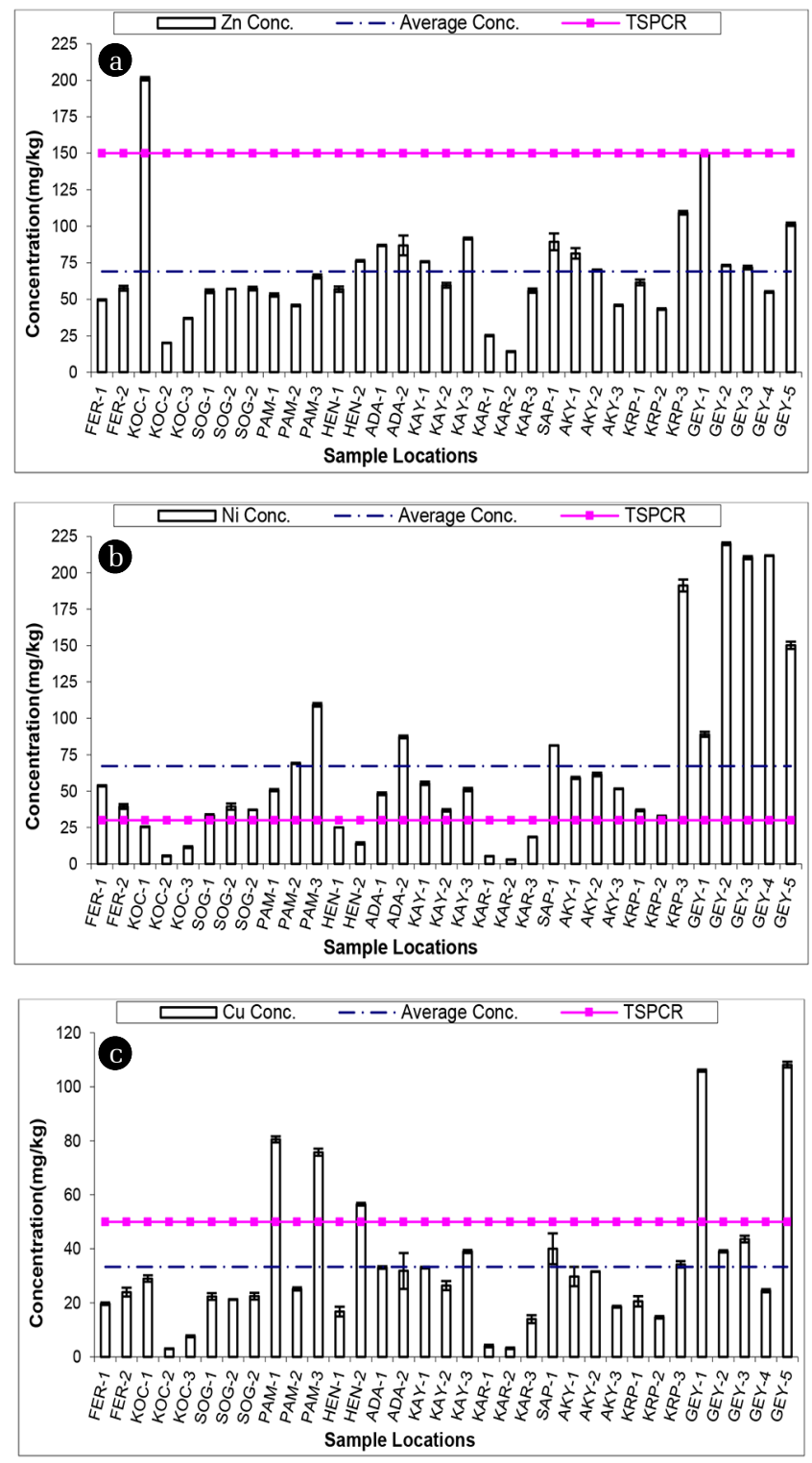

Fig. 3. Heavy metal concentrations in agricultural soil samples of Sakarya. (a) Zn concentrations, (b) Ni concentrations, (c) Cu concentrations. TSPCR: The limit value in the Turkish Soil Pollution Control Regulation (TSPCR). Average Conc.: Average value of all samples. Concentration is given as $\mathrm{mg}$ heavy metal per $\mathrm{kg}$ of collected soil on a dry weight basis.

highest As concentration was measured as $18.1 \mathrm{mg} / \mathrm{kg}$ in ADA-2 sample due to inappropriate discharge conditions of the factories and spreading out of arsenic-containing dust to air and water from mining activities. For $\mathrm{Pb}$, the highest values were found in SAP-1 and KRP-3 samples, even though the values were less than that of the $50 \mathrm{mg} / \mathrm{kg}$ value in TSPCR. The small and large scale industries and overpopulation in the region where SAP-1 and KRP-3 samples were collected play an important role in the contaminant levels in the soil samples. Moreover, Sapanca County is the tourism center in Marmara Region and Lake Sapanca is one of the biggest
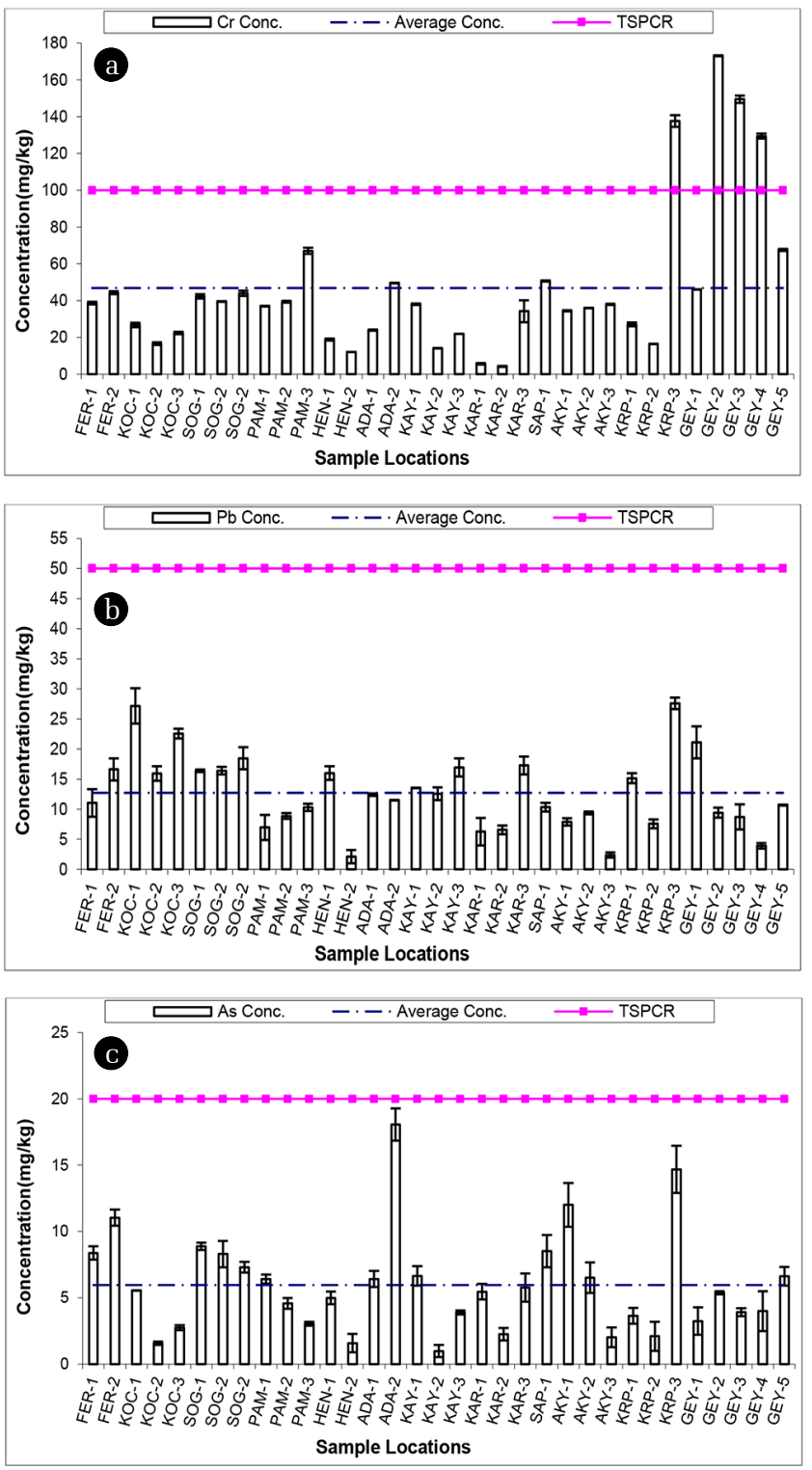

Fig. 4. Heavy metal concentrations in agricultural soil samples of Sakarya. (a) Cr concentrations, (b) Pb concentrations, (c) As concentrations. TSPCR: The limit value in the Turkish Soil Pollution Control Regulation (TSPCR). Average Conc.: Average value of all samples. Concentration is given as mg heavy metal per $\mathrm{kg}$ of collected soil on a dry weight basis.

natural drinking water sources in Turkey. Consequently, caution should be taken when sustainable uses of natural resources and protection of the Lake Sapanca from organic and inorganic pollutants.

\section{Conclusions}

This work reported the levels of PAH (naphthalene, phenanthrene, 
pyrene, and fluoranthene) and heavy metal (As, $\mathrm{Cd}, \mathrm{Cu}, \mathrm{Cr}, \mathrm{Ni}$, $\mathrm{Pb}, \mathrm{Zn}$ ) concentrations in agricultural soils of Sakarya. Total 33 agricultural soils were selected from 12 counties of Sakarya based upon the results of the survey. While $20.34 \mathrm{ng} / \mathrm{g}$ of the highest naphthalene concentration was found in Kocaali County, the highest phenanthrene, pyrene, and fluoranthene concentrations were measured as $63.50 \mathrm{ng} / \mathrm{g}, 134,34 \mathrm{ng} / \mathrm{g}, 140.0 \mathrm{ng} / \mathrm{g}$, respectively in the soil samples from Geyve Country. Similar to PAH concentrations, $\mathrm{Cu}, \mathrm{Ni}$, and $\mathrm{Cr}$ concentrations were measured as $108.2 \mathrm{mg} / \mathrm{kg}, 219.9$ $\mathrm{mg} / \mathrm{kg}$, and $173.1 \mathrm{mg} / \mathrm{kg}$, respectively in Geyve's samples which were the highest and 2-7 times more than the limit values given in the Turkish Soil Pollution Control Regulation. Although this study covers local data on some heavy metal and PAH concentrations of the cucurbits produced soils in Sakarya, it will lead to detailed research on the agricultural soils of Turkey. Precautions need to be taken for Sakarya's agricultural fields which are an important milestone of Turkey's fruit production since the contaminants can be accumulated in the fruits and edible parts of the plants.

\section{Acknowledgments}

This research was funded by the Scientific Research Project of Sakarya University (Grant \# 2007-01-12-003).

\section{References}

1. Lim LH, Harrison RM, Harrad S. The contribution of traffic to atmospheric concentrations of polycyclic aromatic hydrocarbons. Environ. Sci. Technol. 1999;33:3538-3542.

2. Neff JM. Polycyclic aromatic hydrocarbons in the aquatic environment: Sources, fates, and biological effects: Applied Science Publishers; 1979. p. 262.

3. Mulligan CN, Yong RN, Gibbs BF. Remediation technologies for metal-contaminated soils and groundwater: An evaluation. Eng. Geol. 2001;60:193-207.

4. Kelly BC, Gobas FAPC. Bioaccumulation of persistent organic pollutants in lichen-caribou-wolf food chains of Canada's Central and Western Arctic. Environ. Sci. Technol. 2001;35: 325-334.

5. Saleh TA. Advanced nanomaterials for water engineering, treatment, and hydraulics. Hershey, PA: IGI Global; 2017.

6. Saleh TA. Nanomaterial and polymer membranes: Synthesis, characterization, and applications. Waltham, MA: Elsevier; 2016.

7. Saleh TA. Isotherm, kinetic, and thermodynamic studies on $\mathrm{Hg}$ (II) adsorption from aqueous solution by silica- multiwall carbon nanotubes. Environ. Sci. Pollut. R. 2015;22:16721-16731.

8. Saleh TA. Nanocomposite of carbon nanotubes/silica nanoparticles and their use for adsorption of $\mathrm{Pb}(\mathrm{II})$ : From surface properties to sorption mechanism. Desalin. Water Treat. 2016;57: 10730-10744.

9. Saleh TA. Mercury sorption by silica/carbon nanotubes and silica/activated carbon: A comparison study. J. Water Supply Res. Technol. 2015;64:892-903.

10. Gupta VK, Ali I, Saleh TA, Nayak A, Agarwal S. Chemical treatment technologies for waste-water recycling - An overview. RSC Adv. 2012;2:6380-6388.

11. Saleh TA. Simultaneous adsorptive desulfurization of diesel fuel over bimetallic nanoparticles loaded on activated carbon. J. Clean. Prod. 2018;172:2123-2132.

12. Saleh TA, Gupta VK. Processing methods, characteristics and adsorption behavior of tire derived carbons: A review. Adv. Colloid Interface Sci. 2014;211:93-101.

13. Holma-Suutari A, Ruokojarvi P, Laaksonen S, et al. Persistent organic pollutant levels in semi-domesticated reindeer (Rangifer tarandus tarandus L.), feed, lichen, blood, milk, placenta, foetus and calf. Sci. Total Environ. 2014;476:125-135.

14. Bishop CA, Rouse JD. Chlorinated hydrocarbon concentrations in plasma of the Lake Erie water snake (Nerodia sipedon insularum) and northern water snake (Nerodia sipedon sipedon) from the Great Lakes basin in 1998. Arch. Environ. Contam. Toxicol. 2000;39:500-505.

15. Kaupp H, Blumenstock M, McLachlan MS. Retention and mobility of atmospheric particle-associated organic pollutant PCDD/Fs and PAHs in maize leaves. New Phytol. 2000;148: 473-480.

16. Liang YC, Sun WC, Zhu YG, Christie P. Mechanisms of silicon-mediated alleviation of abiotic stresses in higher plants: A review. Environ. Pollut. 2007;147:422-428.

17. Watts AW, Ballestero TP, Gardner KH. Uptake of polycyclic aromatic hydrocarbons (PAHs) in salt marsh plants Spartina alterniflora grown in contaminated sediments. Chemosphere 2006;62:1253-1260.

18. Gumgum B, Unlu E, Tez Z, Gulsun Z. Heavy-metal pollution in water, sediment and fish from the Tigris River in Turkey. Chemosphere 1994;29:111-116.

19. Kabata-Pendias A. Trace elements in soils and plants. CRC Press; 2010. p. 548.

20. Oves M, Saghir KM, Huda QA, Nadeen FM, Almeelbi T. Heavy metals: Biological importance and detoxification strategies. J. Bioremediat. Biodegrad. 2016;7:1-15.

21. Reichman SM. The responses of plants to metal toxicity: A review focusing on copper, manganese and zinc. Australian Minerals and Energy Environment Foundation; 2002.

22. Zawoznik MS, Groppa MD, Tomaro ML, Benavides MP. Endogenous salicylic acid potentiates cadmium-induced oxidative stress in Arabidopsis thaliana. Plant Sci. 2007;173:190-197.

23. Ogundiran $\mathrm{MB}$, Osibanjo O. Heavy metal concentrations in soils and accumulation in plants growing in a deserted slag dumpsite in Nigeria. Afr. J. Biotechnol. 2008;7:3053-3060.

24. Azevedo RA, Gratao PL, Monteiro CC, Carvalho RF. What is new in the research on cadmium-induced stress in plants? Food Energy Secur. 2012;1:133-140.

25. Hughes MF, Beck BD, Chen Y, Lewis AS, Thomas DJ. Arsenic exposure and toxicology: A historical perspective. Toxicol. Sci. 2011;123:305-332.

26. Shanker AK, Cervantes C, Loza-Tavera H, Avudainayagam S. Chromium toxicity in plants. Environ. Int. 2005;31:739-753.

27. Jin RF, Liu Y, Liu GF, Tian T, Qiao S, Zhou JT. Characterization of product and potential mechanism of $\mathrm{Cr}(\mathrm{VI})$ reduction by anaerobic activated sludge in a sequencing batch reactor. Sci. Rep. 2017;7:1681. 
28. Prasad MNV. Heavy metal stress in plants: From biomolecules to ecosystems. Springer Verlag Berlin Heidelberg GmbH; 2004.

29. Ali H, Khan E, Sajad MA. Phytoremediation of heavy metals - Concepts and applications. Chemosphere 2013;91:869-881.

30. Hasan SA, Fariduddin Q, Ali B, Hayat S, Ahmad A. Cadmium: Toxicity and tolerance in plants. J. Environ. Biol. 2009;30: 165-174.

31. Nagajyoti PC, Lee KD, Sreekanth TVM. Heavy metals, occurrence and toxicity for plants: A review. Environ. Chem. Lett. 2010;8:199-216.

32. Andersen V, Maage A, Johannessen P. Heavy metals in blue mussels (Mytilus edulis) in the Bergen Harbor Area, Western Norway. Bull. Environ. Contam. Toxicol. 1996;57:589-596.

33. Zhai XQ, Li ZW, Huang B, et al. Remediation of multiple heavy metal-contaminated soil through the combination of soil washing and in situ immobilization. Sci. Total Environ. 2018;635: 92-99.

34. Parthasarathi R, Sivakumaar PK. Biosurfactant mediated remediation process evaluation on a mixture of heavy metal spiked topsoil using soil column and batch washing methods. Soil Sediment Contam. 2011;20:892-907.

35. Gao JB, Zhao J, Dong CX, Wu LH, Hu PJ. Remediation of metal-contaminated paddy soils by chemical washing with $\mathrm{FeCl}_{3}$ and citric acid. J. Soil. Sediment. 2018;18:1020-1028.

36. Fedje KK, Yillin L, Stromvall AM. Remediation of metal polluted hotspot areas through enhanced soil washing - Evaluation of leaching methods. J. Environ. Manage. 2013;128:489-496.

37. White JC. Phytoremediation of weathered $p, p^{\prime}$-DDE residues in soil. Int. J. Phytoremediat. 2000;2:133-144.

38. De La Torre-Roche R, Hawthorne J, Musante C, et al. Impact of Ag nanoparticle exposure on $p, p^{\prime}$-DDE bioaccumulation by Cucurbita pepo (zucchini) and Glycine max (soybean). Environ. Sci. Technol. 2013;47:718-725.

39. Mattina MII, Iannucci-Berger W, Eitzer BD, White JC. Rhizotron study of cucurbitaceae: Transport of soil-bound chlordane and heavy metal contaminants differs with genera. Environ. Chem. 2004;1:86-89.

40. Mattina MI, Lannucci-Berger W, Musante C, White JC. Concurrent plant uptake of heavy metals and persistent organic pollutants from soil. Environ. Pollut. 2003;124:375-378.

41. Akeem OB, Bassam ST, Amjad BK, Christopher RB, Tawfik AS. Phytoremediation of cadmium-, lead- and nickel-contaminated water by Phragmites australis in hydroponic systems. Ecol. Eng. 2018;120:126-133.

42. White JC. Differential bioavailability of field-weathered
p,p'-DDE to plants of the Cucurbita and Cucumis genera. Chemosphere 2002;49:143-152.

43. White JC, Parrish ZD, Isleyen M, et al. Uptake of weathered $p, p^{\prime}$-DDE by plant species effective at accumulating soil elements. Microchem. J. 2005;81:148-155.

44. White JC, Wang XP, Gent MPN, et al. Subspecies-level variation in the phytoextraction of weathered $p, p$-DDE by Cucurbita pepo. Environ. Sci. Technol. 2003;37:4368-4373.

45. TUIK. Agricultural structure production, price, value. Turkish Statistical Institute, Ankara, Turkey; 2016.

46. Isleyen M, Sevim P, Uslan M. DDX profiles in agricultural fields used for cucurbit production in Sakarya, Turkey. Soil Sediment Contam. 2013;22:689-700.

47. Mattina MJI, Iannucci-Berger W, Dykas L, Pardus J. Impact of long-term weathering, mobility, and land use on chlordane residues in soil. Environ. Sci. Technol. 1999;33:2425-2431.

48. Stilwell DE, Graetz TJ. Copper, chromium, and arsenic levels in soil near highway traffic sound barriers built using CCA pressure-treated wood. Bull. Environ. Contam. Toxicol. 2001;67: 303-308.

49. Mattina MI, Isleyen M, Eitzer BD, Iannucci-Berger W, White JC. Uptake by Cucurbitaceae of soil-borne contaminants depends upon plant genotype and pollutant properties. Environ. Sci. Technol. 2006;40:1814-1821.

50. Telli-Karakoc F, Tolun L, Henkelmann B, Klimm C, Okay O, Schramm KW. Polycyclic aromatic hydrocarbons (PAHs) and polychlorinated biphenyls (PCBs) distributions in the Bay of Marmara sea: Izmit Bay. Environ. Pollut. 2002;119:383-397.

51. Broadley MR, White PJ, Hammond JP, Zelko I, Lux A. Zinc in plants. New Phytol. 2007;173:677-702.

52. Sisman I, Imamoglu M, Aydin AO. Determination of heavy metals in roadside soil from Sapanca Area Highway, Turkey. Int. J. Environ. Pollut. 2002;17:306-311.

53. Chen CY, Huang DJ, Liu JQ. Functions and toxicity of nickel in plants: Recent advances and future prospects. Clean-Soil Air Water 2009;37:304-313.

54. Siddiqui $\mathrm{MH}$, Al-Whaibi MH, Basalah MO. Interactive effect of calcium and gibberellin on nickel tolerance in relation to antioxidant systems in Triticum aestivum L. Protoplasma 2011;248:503-511.

55. Altundag H, Albayrak S, Dundar M, Tuzen M, Soylak M. Investigation of the influence of selected soil and plant properties from Sakarya, Turkey, on the bioavailability of trace elements by applying an in vitro digestion model. Biol. Trace Element Res. 2015;168:276-285. 